\title{
Preprosubtilisin Carlsberg processing and secretion is blocked after deletion of amino acids 97-101 in the mature part of the enzyme
}

\author{
Ralf Schülein, Jürgen Kreft, Sigrid Gonski* and Werner Goebel \\ Institut für Genetik und Mikrobiologie, Universität Würzburg, Röntgenring 11, W-8700 Würzburg, FRG
}

Received September 25, 1990/December 12, 1990

Summary. During an investigation into the substrate specificity and processing of subtilisin Carlsberg from Bacillus licheniformis, two major independent findings were made: (i) as has been shown previously, a stretch of five amino acids (residues 97-101 of the mature enzyme) that loops out into the binding cleft is involved in substrate binding by subtilisin Carlsberg. In order to see whether this loop element also determines substrate specificity, the coding region for these five amino acids was deleted from the cloned gene for subtilisin Carlsberg by site-directed mutagenesis. Unexpectedly the resulting mutant preproenzyme $\left(\mathrm{P} 42 \mathrm{c}, \mathrm{M}_{\mathrm{r}}=42 \mathrm{kDa}\right)$ was not processed to the mature form $\left(M_{r}=30 \mathrm{kDa}\right)$ and was not released into the medium by a proteasedeficient $B$. subtilis host strain; rather, it accumulated in the cell membrane. This result demonstrates that the integrity of this loop element, which is very distant from the processing cleavage sites in the preproenzyme, is required for secretion of subtilisin Carlsberg. (ii) In culture supernatants from $B$. subtilis harbouring the cloned wild-type subtilisin Carlsberg gene the transient appearance (at $0-3 \mathrm{~h}$ after onset of stationary phase) of a processing intermediate $\left(\mathrm{P} 38 \mathrm{c}, \mathrm{M}_{\mathrm{r}}=38 \mathrm{kDa}\right)$ of this protease could be demonstrated. P38c very probably represents a genuine proform of subtilisin Carlsberg.

Key words: Bacillus - Proenzyme - Subtilisin maturation - Site-directed mutagenesis - Subtilisin Carlsberg

\section{Introduction}

The subtilisins comprise a group of bacterial serine endopeptidases, which are secreted into the medium by a wide variety of Bacillus species (Markland and Smith 1971). The subtilisin genes from four Bacillus species have been cloned, sequenced and expressed in Bacillus

\footnotetext{
* Present address: Hoechst AG, D-6000 Frankfurt/M, Germany Offprint requests to: $\mathrm{J}$. Kreft
}

subtilis (reviewed in Wells et al. 1987a). Among these were the genes for subtilisin Carlsberg from $B$. licheniformis (Jacobs et al. 1985; Berger et al. 1987) and for subtilisin $\mathrm{BPN}^{\prime}$ from B. amyloliquefaciens (Wells et al. 1983; Vasantha et al. 1984). Many attempts have been made to modify the enzymatic properties of subtilisins, e.g. to change substrate specificity (Russell et al. 1987; Wells et al. $1987 \mathrm{a}$ ). The closely related subtilisins Carlsberg and BPN' differ in 84 out of 275 amino acids. In addition one amino acid, at position 56 of subtilisin BPN', is $^{\prime}$ lacking in subtilisin Carlsberg (Smith et al. 1968). The amino acids essential for the catalytic triad are identical in subtilisin Carlsberg and BPN' (Smith et al. 1968) and the substrate binding regions are very similar (Bode et al. 1987; Wells et al. 1987 b) with one notable exception: the sequence Asn97-Ser98-Ser99-Gly100-Ser101 in the Carlsberg enzyme is functionally analogous to Gly97Ala98-Asp99-Gly100-Ser101 in subtilisin BPN' (for maximum alignment the deletion at position 56 has been neglected in this nomenclature) but differs in three out of five amino acids. This loop-forming segment is close to the active site and is apparently involved in substrate/ inhibitor binding (Bode et al. 1987; Wells et al. 1987b) of both subtilisins but differs significantly in three-dimensional structure. It has been proposed by Bode et al. (1987) that this loop element is relatively flexible in free subtilisin species and gains a defined conformation only upon substrate binding. Computer modelling (W. Bode, personal communication) has suggested that removal of this loop should not lead to gross changes in the overall conformation of the protein nor should it completely abolish substrate binding or catalytic activity. Therefore we wondered how such a deletion would influence the substrate specificity of subtilisin Carlsberg.

The alkaline exoproteases from $B$. amyloliquefaciens (Wells et al. 1983; Vasantha et al. 1984), B. subtilis (Stahl and Ferrari 1984) and $B$. licheniformis (Jacobs et al. 1985; Berger et al. 1987) are translated, like bacillar neutral protease, as preprosubtilisins, which contain a large prosequence between the presumptive signal (pre-) sequence and the mature part of the enzyme. There has 
been some controversy about the course of preprosubtilisin processing; we therefore undertook a search for processing intermediates of subtilisin Carlsberg produced from the cloned wild-type gene in B. subtilis.

\section{Materials and methods}

Bacterial strains and growth conditions. B. subtilis DB104 nprE18 nprR2 $\triangle$ aprA3 hisH (from R. Doi), B. subtilis $\mathrm{SB} 202$ trp $C 2$ thy $A B$ aro $B$ (from $\mathrm{H}$. Schaller) and $B$. subtilis BD366 thr5 trpC2 with pUB110 (from BGSC) were grown in HGP medium (15.6 g/l Bacto-peptone, $2.8 \mathrm{~g} / \mathrm{l}$ yeast extract, $5.6 \mathrm{~g} / 1 \mathrm{NaCl}, 1 \mathrm{~g} / 1$ glucose, $\mathrm{pH}$ 7.5) at $37^{\circ} \mathrm{C}$; for plates $1 \%$ Bacto-agar was added. Casein agar for the detection of proteolytic halos consisted of HGP agar with $5 \%(\mathrm{w} / \mathrm{v})$ skim milk powder, autoclaved at $110^{\circ} \mathrm{C}$ for 10 min. Escherichia coli strains and media used for site-specific mutagenesis have been described (Stanssens et al. 1989).

Chemicals. Restriction enzymes were from Pharmacia LKB or from Boehringer Mannheim and were used as indicated by the supplier. $\left[{ }^{32} \mathrm{P}\right] \mathrm{dATP}$ was purchased from Amersham Buchler. All reagents used were analytical grade.

Plasmid isolation was done as previously described for E. coli (Maniatis et al. 1982) and B. subtilis (Kreft et al. 1983).

Site-specific mutagenesis of the subtilisin gene. The gapped-duplex system described by Stanssens et al. (1989) for $E$. coli, with pMac 5-8 as a vector, was used. The mutagenesis primer $\left(5^{\prime}\right.$ GCGGTTAAAGTACTGGGATCATACAGCGGC $3^{\prime}$ ), spanning the codons for Ala92-Val93-Lys94-Val95-Leu96 fused to Gly102-Ser103-Tyr104-Ser105-Gly106 of subtilisin Carlsberg, was synthesized on a 380A DNA synthesizer from Applied Biosystems. The complete determinant for subtilisin Carlsberg from B. licheniformis DSM641 had originally been cloned (Berger et al. 1987) into plasmid pBCE16 (Bernhard et al. 1978). It was subcloned into the mutagenesis vector with $E$. coli as a host, modified by the introduction of an additional BamHI site into the 3 '-flanking region to yield plasmid pGD90, and mutagenized. Plasmids with the desired deletion were identified by the concomitant loss of an EcoRI site. DNA sequencing was done by the dideoxy chain-termination method (Sanger et al. 1977) and revealed that in plasmid pGD4/7 correct deletion of the codons for amino acids 97-101 had taken place.

Transformation of $B$. subtilis protoplasts with pUB110 derivatives was performed according to Chang and Cohen (1979). Transformants were selected on DM3 regeneration plates (Chang and Cohen 1979) with 150 $\mu \mathrm{g} / \mathrm{ml}$ of kanamycin.

Colony hybridization was done as previously described (Notermans et al. 1989) using Gene-Screen-Plus membranes (Du Pont).
Assay of alkaline protease activity. In culture supernatants from $B$. subtilis grown in HGP medium alkaline protease activity was determined by the micro-HPE method (A. Weiss, Henkel KGaA, personal communication). Briefly, $50 \mu \mathrm{l}$ of supernatant was mixed with $150 \mu \mathrm{l}$ of TPP buffer [25 g/l sodium tripolyphosphate in synthetic tap water $\left(0.29 \mathrm{~g} / \mathrm{l} \mathrm{CaCl}{ }_{2} \cdot 2 \mathrm{H}_{2} \mathrm{O}, 0.14 \mathrm{~g} / 1 \mathrm{MgCl}_{2}\right.$. $6 \mathrm{H}_{2} \mathrm{O}, 0.21 \mathrm{~g} / 1 \mathrm{NaHCO}_{3}$ in distilled water, $\mathrm{pH}$ 8.5)] and $600 \mu \mathrm{l}$ of casein substrate $(12 \mathrm{~g} / \mathrm{l}$ casein Hammersten in synthetic tap water, $30 \mathrm{mM}$ TRIS- $\mathrm{HCl}$, $\mathrm{pH}$ 8.5). Incubation was at $60^{\circ} \mathrm{C}$ for $15 \mathrm{~min}$, then $600 \mu \mathrm{l}$ of TCA reagent $(72 \mathrm{~g} / 1$ trichloroacetic acid, $30 \mathrm{~g} / 1$ sodium acetate, $3 \% \mathrm{v} / \mathrm{v}$ acetic acid) was added. After $15 \mathrm{~min}$ on ice, nonhydrolysed substrate was pelleted by centrifugation. To the supernatant $1 / 3$ vol. of $2 \mathrm{~N} \mathrm{NaOH}$ was added and free tyrosine was determined spectrophotometrically at $290 \mathrm{~nm}$ in $1 \mathrm{~cm}$ cuvettes. Unit definition: $1 \mathrm{HPE} /$ $\mathrm{ml}=\left[\left(\mathrm{OD}_{290} \times 20.16\right)-0.09\right] \times$ dilution

Cell lysates and supernatant proteins. B. subtilis cells were grown in $\mathrm{HGP}$ medium at $37^{\circ} \mathrm{C}$ for the times indicated in the text. After harvesting the cells by centrifugation, proteins in the supernatant were precipitated with TCA (final concentration $7 \% \mathrm{w} / \mathrm{v}$ ) in the cold. Cells were washed twice with phosphate-buffered saline (PBS), suspended in lysozyme mix $(10 \mathrm{mg} / \mathrm{ml}$ lysozyme, $10 \mathrm{mM}$ TRIS-HCl, $1 \mathrm{mM}$ disodium EDTA, $\mathrm{pH}$ 8.0) and kept on ice for $15 \mathrm{~min}$. After centrifugation cells were lysed by heating in protein sample buffer (Laemmli 1970) at $96^{\circ} \mathrm{C}$ for $5 \mathrm{~min}$. TCA-precipitated supernatant proteins were neutralized prior to heating with sample buffer.

Membrane fractions from $B$. subtilis were prepared essentially as described (Osborn et al. 1972) following lysozyme treatment of intact cells, but in our case the lysis buffer contained $10 \mathrm{mM}$ TRIS- $\mathrm{HCl}, \mathrm{pH} 7.6$ plus $1 \mathrm{mM}$ phenylmethyl-sulphonylfluoride (PMSF) and $1 \mathrm{mM}$ dithiothreitol.

Polyclonal rabbit antiserum against subtilisin Carlsberg was raised by subcutaneous injection of $1 \mathrm{mg}$ of commercial subtilisin Carlsberg (Sigma) in complete Freund's adjuvant followed by two booster injections (0.5 mg in PBS, intravenous) after 3 and 5 weeks. Crude antiserum was preabsorbed with a cell lysate from $B$. subtilis carrying pUB110 in order to reduce unspecific binding.

Gel electrophoresis ( $S D S-P A G E$ ) and immunoblotting of proteins were done on SDS-polyacrylamide slab gels (Laemmli 1970). Proteins were transferred onto nitrocellulose membranes (Schleicher \& Schuell) by semi-dry blotting (Khyse-Andersen 1984) and detected (Towbin et al. 1979) with rabbit antiserum to subtilisin Carlsberg. Horseradish peroxidase-conjugated anti-rabbit IgG (Dianova) was used as second antibody.

\section{Results}

Cloning in B. subtilis and phenotypic expression

The sequence coding for the loop formed by amino acids 97-101 in the mature part of the enzyme was deleted 
from a cloned wild-type subtilisin Carlsberg gene (Berger et al. 1987) as described in Materials and methods. The effect of this deletion on the enzymatic activity of subtilisin Carlsberg was then tested. The wild-type and mutant genes, present on BamHI fragments from the pMac derivatives pGD90 or pGD4/7 (see Materials and methods), were inserted separately into the unique BamHI site of pUB110 (Gryczan et al. 1978). The ligation mixtures were used to transform protoplasts of $B$. subtilis DB104. This strain is defective in the major neutral and alkaline exoproteases as a result of two point mutations plus one deletion (Kawamura and Doi 1984) and shows no proteolytic background on casein agar. The same strain was transformed with pUB110 as a control. Transformants selected on DM3 regeneration plates with 150 $\mu \mathrm{g} / \mathrm{ml}$ kanamycin were then transferred onto skim milk agar with $20 \mu \mathrm{g} / \mathrm{ml}$ of the antibiotic and incubated overnight at $37^{\circ} \mathrm{C}$. Plasmid DNA was isolated from proteolytic halo-forming $\mathrm{Km}^{\mathrm{r}}$ transformants (9 out of a total of 800 ) obtained with the wild-type fragment and the presence of the wild-type subtilisin gene was confirmed by restriction analysis (data not shown). Since it has been observed ( $\mathrm{K}$. Gamon, Henkel $\mathrm{KGaA}$, personal communication) that high subtilisin Carlsberg expression is dependent on the orientation of the cloned gene in pUB110, only the recombinant plasmid pCAR90 was chosen for the subsequent investigations. In this construct the subtilisin gene is transcribed counterclockwise relative to the common map of pUB110 (Fig. 1).

Transformations of $B$. subtilis DB104 with ligation mixtures containing the mutant BamHI fragment from pGD4/7 repeatedly yielded no proteolytic clones among the $\mathrm{Km}^{\mathrm{r}}$ transformants. However, in colony hybridization experiments using the wild-type BamHI fragment as a probe, two transformants were found to contain a recombinant plasmid consisting of pUB110 and the mutant BamHI fragment in the same orientation as in pCAR90 (data not shown). This plasmid was designated pCAR4/7.

The vector pUB110 and the recombinant plasmids pCAR90 and pCAR4/7 were then introduced via protoplast transformation into the protease-proficient strain $B$. subtilis SB202. The proteolytic activity of the transformants described above was compared by measuring halo formation after plating onto skim milk agar with subsequent incubation at $37^{\circ} \mathrm{C}$ for $48 \mathrm{~h}$. In addition the protease activity in culture supernatants from $B$. subtilis DB104 strains grown in liquid medium for $24 \mathrm{~h}$ at $37^{\circ} \mathrm{C}$ was determined by a standardized spectrophotometric test with casein as a substrate (see Materials and methods). The growth characteristics of the strains tested were identical. Since B. subtilis SB202 is protease proficient itself, no in vitro protease tests were performed in this case. Table 1 summarizes the results from these experiments.

\section{Identification of a subtilisin precursor in the cell membrane}

Several factors could be responsible for the lack of extracellular protease activity observed in the culture superna-

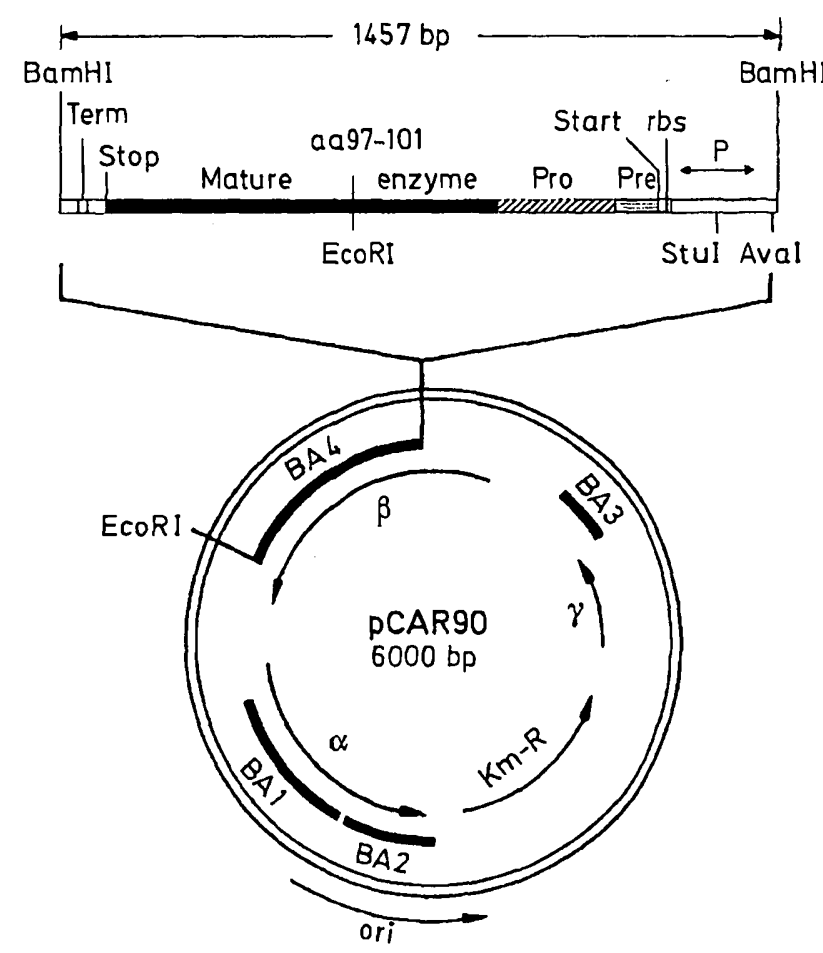

Fig. 1. Structure of pCAR90, containing the complete wild-type determinant for subtilisin Carlsberg from Bacillus licheniformis DSM641. For the construction of the mutant plasmid pCAR4/7 the coding sequence for amino acids $97-101$ in the mature part of the enzyme was deleted. The lower part of the figure represents the vector plasmid pUB110. P, promoter region; rbs, ribosome binding site; Term, transcription terminator; $\mathrm{BA} 1-4$, membrane binding areas; $\mathrm{Km}-\mathrm{R}$, kanamycin resistance gene; $\alpha-\gamma$, open reading frames. Other explanations are given in the text

Table 1. Phenotypic expression and protease activity in culture supernatants

\begin{tabular}{|c|c|c|c|}
\hline $\begin{array}{l}\text { Bacillus subtilis } \\
\text { host strain }\end{array}$ & Plasmid & $\begin{array}{l}\text { Diameter of } \\
\text { proteolytic halo } \\
\text { on skim milk agar } \\
(\mathrm{mm})^{\mathbf{a}}\end{array}$ & $\begin{array}{l}\text { Protease } \\
\text { activity in } \\
\text { supernatant } \\
\text { (HPE/ml) }\end{array}$ \\
\hline \multirow{2}{*}{$\begin{array}{l}\text { DB104 } \\
\text { (protease } \\
\text { deficient) }\end{array}$} & $\begin{array}{l}\text { pUB110 } \\
\text { (vector) }\end{array}$ & No halo & 0 \\
\hline & $\begin{array}{l}\text { PCAR } 90 \\
\text { pCAR } 4 / 7\end{array}$ & $\begin{array}{l}10 \pm 1 \\
\text { No halo }\end{array}$ & $\begin{array}{r}490 \\
0\end{array}$ \\
\hline $\begin{array}{l}\text { SB202 } \\
\text { (protease } \\
\text { proficient) }\end{array}$ & $\begin{array}{l}\text { pUB110 } \\
\text { pCAR90 } \\
\text { pCAR4/7 }\end{array}$ & $\begin{array}{r}9 \pm 1 \\
20 \pm 2 \\
11 \pm 1\end{array}$ & $\begin{array}{l}\mathrm{ND}^{\mathrm{c}} \\
\mathrm{ND} \\
\mathrm{ND}\end{array}$ \\
\hline
\end{tabular}

a Means and mean errors, $n=20$; incubation at $37^{\circ} \mathrm{C}$ for $48 \mathrm{~h}$

b Growth at $37^{\circ} \mathrm{C}$ for $24 \mathrm{~h}$ in HGP medium; see Materials and methods for enzymatic test and unit definition

c Not determined

tant from B. subtilis DB104 with pCAR4/7. One explanation could be that the mutant enzyme is secreted but is enzymatically inactive. Alternatively, the mutation might have resulted in a block in preproenzyme translocation and/or processing. Enhanced intracellular degradation of the mutant preproenzyme could also explain 


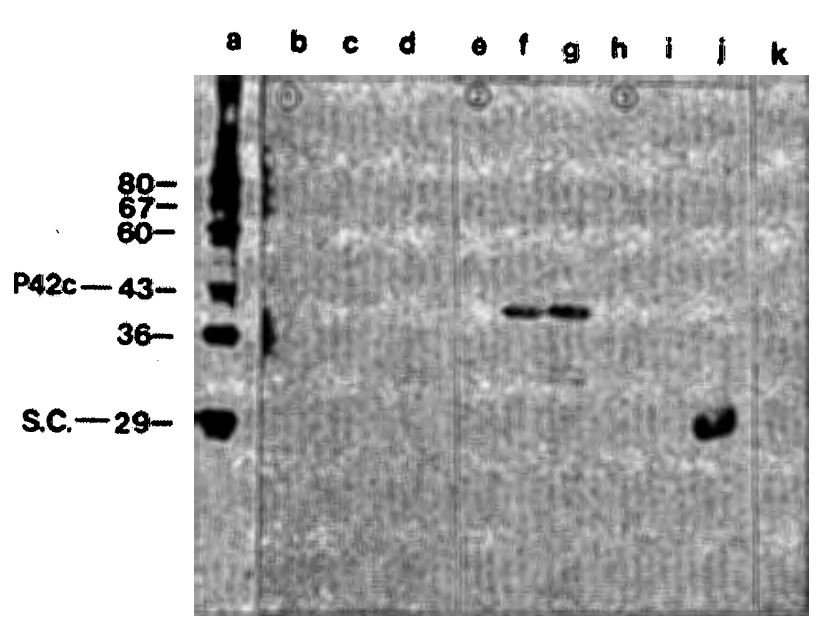

Fig. 2. Immunoblot analysis of proteins reacting with polyclonal anti-subtilisin Carlsberg antiserum (dilution 1:500). Lane a, marker proteins (indian ink stain), molecular weights in kilodaltons. Lanes b-j, cytoplasm (panel 1), membrane fractions (2) and culture supernatants (3) from Bacillus subtilis DB104 with the vector pUB110 (lanes b, e, h), with pCAR4/7 (mutant, lanes $c, f$, i) or with pCAR90 (wild type, lanes $d, g, j$ ). Lane $k$, culture supernatant from $B$. subtilis SB202 with pCAR4/7. S.C. indicates mature subtilisin Carlsberg, P42c is explained in the text

our observations. In order to distinguish between these possibilities, cell membranes, cytoplasmic fractions and culture supernatants from $B$. subtilis DB104 with the vector $\mathrm{pUB} 110$, with $\mathrm{pCAR} 90$ or with $\mathrm{pCAR} / 7$, respectively, grown for $24 \mathrm{~h}$ at $37^{\circ} \mathrm{C}$ in HGP medium, were prepared as described in Materials and methods. Aliquots corresponding to about $2 \times 10^{8}$ cells (supernatant and cytoplasm) or $6 \times 10^{8}$ cells (membranes), were electrophoresed on SDS-polyacrylamide slab gels. In immunoblots with anti-subtilisin Carlsberg antiserum (Fig. 2) no cross-reacting material was detectable in the cytoplasmic fractions (lanes $b-d$ ). Only in the case of pCAR90 (wild-type gene) was a reactive protein with an apparent molecular weight of $30 \mathrm{kDa}$, typical of mature subtilisin observed in the supernatants (lane j). No immunoreactive protein was detectable in the culture supernatant from the same number of $B$. subtilis DB104 pCAR4/7 cells (lane i); the same was true when tenfold higher amounts of supernatant proteins were tested (data not shown). With B. subtilis SB202 as host for pCAR4/7 a faint immunoreactive band appeared in the culture supernatant (lane $\mathrm{k}$ ); however, such a faint reaction could also be due to cross-reaction with subtilisin E from this protease-proficient host or with an as yet unidentified protein also found in the protease-deficient DB104 strain (lanes h, i). Analysis of the membrane fractions revealed a cross-reactive protein with an apparent molecular weight of $42 \mathrm{kDa}$ (P42c) for $B$. subtilis DB104 containing pCAR90 (lane g) or pCAR4/7 (lane f), which was absent from cells containing only the vector plasmid pUB110 (lane e). Such a molecular weight would be expected for the preproform of subtilisin Carlsberg. With the wild-type enzyme, in addition to P42c,

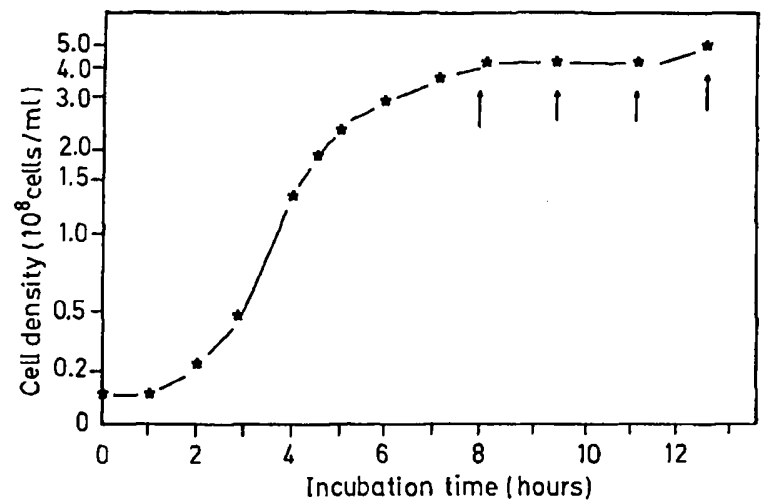

Fig. 3. Growth curve of Bacillus subtilis DB104 carrying pCAR90 in HGP medium at $37^{\circ} \mathrm{C}$. Sampling times are indicated by arrows

a large number of smaller cross-reacting proteins were found in the membrane fraction (lane $\mathrm{g}$ ); in the case of the mutant (lane f) no such degradation products were detectable.

\section{Detection of a processing intermediate of subtilisin Carlsberg in culture supernatants}

As previously demonstrated, the primary translation product of the subtilisin Carlsberg gene is much longer than the mature enzyme and contains a rather long proregion (76 amino acids) adjacent to the presumptive $\mathrm{N}$ terminal signal peptide (pre-region, 29 amino acids). However, a processing intermediate consisting only of the pro-region together with the mature part of the enzyme (prosubtilisin) has not been detected in bacilli. There is good evidence that the maturation of prosubtilisin is an autocatalytic process and is initiated by intramolecular cleavage of the propeptide (Ikemura and Inouye 1988). Taking this into account we determined whether a processing intermediate of subtilisin Carlsberg was detectable very early after the onset of protease synthesis and secretion, i.e. in early stationary phase. Figure 3 shows the growth curve of $B$. subtilis DB104 carrying pCAR90 (wild-type gene), grown in HGP medium at $37^{\circ} \mathrm{C}$. No protease was detected in the culture supernatant until the end of the logarithmic growth phase; the same held true for $B$. licheniformis DSM641 from which the cloned protease gene was derived (unpublished results). Immediately after entry of the culture into stationary phase (at $8 \mathrm{~h}$ ) and at $9.5,11$ and $12.5 \mathrm{~h}$, samples were taken and the proteins in the cell lysates and in the supernatants were analysed by SDS-PAGE and immunoblotting as described above. Each aliquot of proteins on the gel corresponded to the same cell number $\left(2.4 \times 10^{8}\right.$ cells $)$ thus allowing for direct comparison of relative protein concentrations. Figure 4 shows that at the beginning of stationary phase $(8 \mathrm{~h})$, in addition to mature subtilisin Carlsberg, a strong protein band $\left(\mathrm{M}_{\mathrm{r}}=\right.$ $38 \mathrm{kDa}$ ) cross-reacting with anti-subtilisin Carlsberg was detectable in the culture supernatant. The concentration 


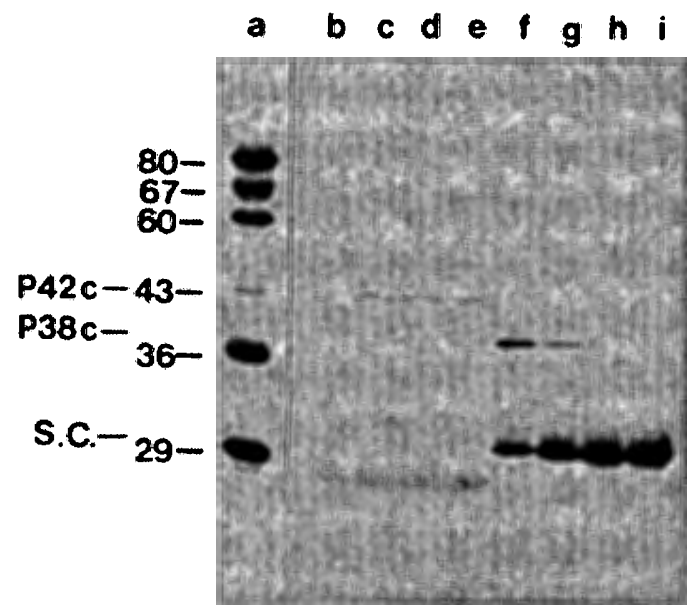

Fig. 4. Immunoblot with polyclonal anti-subtilisin Carlsberg antiserum (dilution 1:500) of proteins from Bacillus subtilis DB104 carrying pCAR90. At different times during growth (see Fig. 3) samples containing equal numbers of cells were analysed. Lane a, marker proteins (indian ink stain), molecular weights in kilodaltons. Lanes b-e, cell lysates, and $f-i$, culture supernatant proteins after $8,9.5$, 11 and $12.5 \mathrm{~h}$ of culture, respectively. S.C. indicates mature subtilisin Carlsberg, P42c and P38c are explained in the text.

of this protein (P38c) decreased over the next $3 \mathrm{~h}$ concomitant with a proportional increase in the concentration of the mature enzyme. The amount of precursor (P42c) in the cell lysates was low when enzyme synthesis started (lane b). If one assumes that precursor synthesis and processing proceed at a constant rate after the initial phase, the amount of P42c in the cell lysate should reach an optimum and then remain constant as long as synthesis continues (Fig. 4, lanes c-e). The diffuse immunoreactive protein band with an apparent molecular weight slightly lower than mature subtilisin Carlsberg which appeared in the cell lysates most probably represents the major intracellular serine protease of the $B$. subtilis host which has a high degree of homology to subtilisin (Koide et al. 1986). This protein was also detectable in preparations from $B$. subtilis carrying only the vector pUB110.

\section{Discussion}

The data presented here have several implications regarding the time course and mechanism of subtilisin Carlsberg biosynthesis, processing and secretion. The calculated molecular weight of the mature enzyme is 27.3 $\mathrm{kDa}$; however, in the gel system used here its apparent molecular weight was $30 \mathrm{kDa}$. This discrepancy has also been observed for subtilisin BPN' (Wells et al. 1983). The calculated molecular weight for the prepropeptide of the Carlsberg enzyme is $11.6 \mathrm{kDa}$, therefore one would expect an apparent molecular weight of about $42 \mathrm{kDa}$ for the preproenzyme. No precursor form of this size and no material cross-reacting with anti-subtilisin was detectable in the cytoplasmic fraction of $B . s u b$ tilis DB104 (a protease-deficient host) that contained and phenotypically expressed the cloned wild-type sub- tilisin Carlsberg gene. This result could reflect a very rapid conversion of the translation product into a membrane-bound form so that the concentration of the free protein was below the level of detection. Alternatively, synthesis of preprosubtilisin may occur in close association with the cytoplasmic membrane without any free cytoplasmic form. A similar observation has been reported for the cloned subtilisin $\mathrm{BPN}^{\prime}$ gene (Power et al. 1986). In the same strain containing either the cloned wild-type (pCAR90) or the mutant (pCAR4/7) subtilisin Carlsberg gene, we detected a cross-reacting protein exclusively in the membrane fraction with an apparent molecular weight of $42 \mathrm{kDa}(\mathrm{P} 42 \mathrm{c})$, as expected for the preproenzyme. We could not detect any larger protein cross-reacting with anti-subtilisin Carlsberg in the membrane preparations. Therefore we suggest that P42c is true preprosubtilisin, although its $\mathrm{N}$-terminal amino acid sequence has not yet been determined.

One aim of our study with subtilisin Carlsberg was to investigate how a deletion of the loop-forming element Asn97-Gly102 would influence substrate specificity. This element has been shown to be part of the substrate binding region (Bode et al. 1987) but is apparently not absolutely required for substrate binding. Therefore one would expect some residual proteolytic activity in culture supernatants from $B$. subtilis carrying such a mutant protease gene, or at least some immunologically cross-reacting material. This clearly was not the case here with the protease-deficient DB104 strain as a host. In the cell membrane fraction from the same strain the amount of preprosubtilisin (P42c) was comparable to the amount in a strain with the wild-type gene, indicating that substantial amounts of the mutant enzyme were made intracellularly. No degradation products of prepro- or mature enzyme could be detected in the cytoplasm, membrane fraction or in the culture supernatant from the mutant strain. Therefore enhanced degradation of the mutant enzyme as a cause of the lack of phenotypic expression is very unlikely. When the mutant gene was expressed in the protease-proficient $B$. subtilis strain SB202 a slight increase in proteolytic activity was seen when measured by halo formation on skim milk agar. In the culture supernatant from this strain the amount of immunoreactive protein comigrating with mature subtilisin was negligible when compared with the situation with the wild-type gene in the DB104 strain. In addition this material could not be identified unambiguously as the Carlsberg enzyme because of the observed weak cross-reactivity with host strain proteins. It is possible that the presence of the mutant subtilisin Carlsberg gene together with its regulatory sequences on a multicopy plasmid titrates a postulated factor (Park et al. 1989) that negatively controls subtilisin expression, thus leading to increased protease expression from the chromosome of the protease-proficient host.

Several models have been' proposed for the secretion and processing of extracellular proteases of bacilli. The failure to detect a proform of subtilisin $\mathrm{BPN}^{\prime}$ has prompted a model in which the preproform is translocated through the membrane and then cleaved autocatalytically and exclusively between the pro-region and the ma- 
ture part of the enzyme without the participation of signal peptidase. This notion was supported by the fact that mutations in the active site of subtilisin BPN' prevented processing of preprosubtilisin without the appearance of proenzyme (Power et al. 1986). On the other hand, it has been shown that preprosubtilisin of $B$. subtilis can be cleaved in vitro at the presumptive signal peptidase cleavage site by membrane vesicles from the protease-deficient strain B. subtilis DB104 (Wong and Doi 1986). In the same work it was shown that a fusion protein consisting of the subtilisin signal sequence and the mature part of the $E$. coli TEM $\beta$-lactamase was processed by $B$. subtilis in vivo at the predicted signal peptidase cleavage site. Very similar results have been reported by others (Vasantha and Thompson 1986), indicating that the mature, proteolytically active portion of subtilisin is not required for the cleavage of the prepeptide from such fusion proteins. As discussed below, we were able to detect a processing intermediate of subtilisin Carlsberg (P38c) that apparently lacked the presequence. The appearance of this intermediate should not depend on the proteolytic activity of the mature enzyme, as discussed above. However, we could not detect any proform of the mutant enzyme expressed from pCAR4/7. Considering all these, albeit controversial, data the most likely explanation for the block in secretion of the mutant subtilisin Carlsberg is that the loop deletion results in a translocation-incompetent precursor protein. Another explanation could be that the mutant preproenzyme is still translocated but cannot be released because the loop element is directly involved in the cleavage of the prepeptide. This idea remains, however, pure speculation as long as the mechanism of this cleavage is not completely understood.

Another new finding of this study was the detection of $\mathrm{P} 38 \mathrm{c}$ in the culture supernatant from $B$. subtilis DB104 carrying the cloned wild-type subtilisin Carlsberg gene on pCAR90. The calculated molecular weight of the prosequence of this enzyme is $8.3 \mathrm{kDa}$, which corresponds very well with the observed difference in the apparent molecular weights of mature subtilisin and P38c. This protein was detectable only transiently after the onset of subtilisin synthesis, i.e. in early stationary phase. The amount of P38c in the culture supernatant then rapidly decreased concomitant with an increase in the amount of mature enzyme, suggesting a precursor-product relationship between these two proteins. The failure to detect such a proform for subtilisin $\mathrm{BPN}^{\prime}$, when the cloned gene was expressed in $B$. subtilis (Wells et al. 1983; Power et al. 1986), could be explained by the appearance of low levels of protease in the culture supernatant as soon as in the late logarithmic growth phase as has been observed by Power et al. (1986). In the same report it was shown that subtilisin $\mathrm{BPN}^{\prime}$ can be processed in trans by mature enzyme in the supernatant. If the production of protease increases slowly, as was the case there, the amount of mature subtilisin should always be sufficient for a very rapid turnover of the proenzyme and, as these authors stated, a proform of subtilisin BPN' might have gone undetected (Power et al. 1986). In the case of subtilisin Carlsberg, where enzyme synthesis starts late and increases rapidly, the processing of a presumptive proenzyme is thought to be delayed in the initial phase. Therefore we suggest that P38c is not an artefact due to overproduction but represents a genuine proform of subtilisin Carlsberg.

Acknowledgements. The authors wish to thank W. Bode (Martinsried) for helpful suggestions, M. Dumbsky for expert technical assistance, H. Hof (Mannheim) for help in the preparation of antiserum, R. Doi (Davis) for the donation of B. subtilis DB104 and $M$. Wuenscher for critical reading of the manuscript. We are greatly indebted to Henkel $\mathrm{KGaA}$ (Düsseldorf) for their financial support.

\section{References}

Berger H, Goebel W, Kreft J, Bartnik F (1987) Alkalische Protease, Verfahren zur Herstellung von Hybridvektoren und genetisch transformierte Mikroorganismen. German patent DE 3527913A1

Bernhard K, Schrempf H, Goebel W (1978) Bacteriocin and antibiotic resistance plasmids in Bacillus cereus and Bacillus subtilis. J Bacteriol 133: 897-903

Bode W, Papamokos E, Musil D (1987) The high-resolution X-ray crystal structure of the complex formed between subtilisin Carlsberg and eglin c, an elastase inhibitor from the leech Hirudo medicinalis. Eur J Biochem 166:673-692

Chang S, Cohen SN (1979) High frequency transformation of $B a$ cillus subtilis protoplasts by plasmid DNA. Mol Gen Genet 168:111-115

Gryczan TJ, Contente S, Dubnau D (1978) Characterization of Staphylococcus aureus plasmids introduced by transformation into Bacillus subtilis. J Bacteriol 134:316-329

Ikeumura $\mathrm{H}$, Inouye $\mathrm{M}$ (1988) In vitro processing of pro-subtilisin produced in Escherichia coli. J Biol Chem 263:12959-12963

Jacobs M, Eliasson M, Uhlen M, Flock JI (1985) Cloning, sequencing and expression of subtilisin Carlsberg from Bacillus licheniformis. Nucleic Acids Res 13:8913-8926

Kawamura F, Doi RH (1984) Construction of a Bacillus subtilis double mutant defective in extracellular alkaline and neutral proteases. J Bacteriol 160:442-444

Koide Y, Nakamura A, Uozumi T, Beppu T (1986) Cloning and sequencing of the major intracellular serine protease gene of Bacillus subtilis. J Bacteriol 167:110-116

Kreft J, Berger H, Härtlein M, Müller B, Weidinger G, Goebel W (1983) Cloning and expression in Escherichia coli and Bacillus subtilis of the hemolysin (cereolysin) determinant from Bacillus cereus. J Bacteriol 155:681-689

Kyhse-Andersen J (1984) Electroblotting of multiple gels: a simple apparatus without buffer tank for rapid transfer of proteins from polyacrylamide to nitrocellulose. J Biochem Biophys Methods 10:203-209

Laemmli UK (1970) Cleavage of structural proteins during the assembly of the head of the bacteriophage T4. Nature 227:680685

Maniatis T, Fritsch EF, Sambrook J (1982) Molecular cloning: a laboratory manual. Cold Spring Harbor Laboratory Press, Cold Spring Harbor, New York

Markland FS, Smith EL (1971) Subtilisins: Primary structure, chemical and physical properties. In: Boyer PD (ed) The enzymes, vol III. Academic Press, New York, pp 561-608

Notermans S, Chakraborty T, Leimeister-Wächter M, Dufrenne J, Heuvelmann KJ, Maas H, Jansen W, Wernars K, Guinee $\mathrm{P}$ (1989) Specific gene probe for detection of biotyped and serotyped Listeria strains. Appl Environ Microbiol 55:902-906

Osborn MJ, Gander JE, Parisi E, Carson J (1972) Mechanism of assembly of the outer membrane of Salmonella typhimurium. J Biol Chem 247:3962-3972

Park SS, Wong SL, Wang LF, Doi RH (1989) The Bacillus subtilis subtilisin gene $(a p r E)$ is expressed from a $\sigma^{A}\left(\sigma^{43}\right)$ promoter in vitro and in vivo. J Bacteriol 171:2657-2665 
Power SD, Adams RM, Wells JA (1986) Secretion and autoproteolytic maturation of subtilisin. Proc Natl Acad Sci USA 83:3096-3100

Russell AJ, Thomas PG, Fersht AR (1987) Electrostatic effects on modification of charged groups in the active site cleft of subtilisin by protein engineering. J Mol Biol 193:803-813

Sanger F, Nicklen S, Coulson HR (1977) DNA sequencing with chain-terminating inhibitors. Proc Natl Acad Sci USA 74:5463-5467

Smith EL, DeLange RJ, Evans WH, Landon M, Markland FS (1968) Subtilisin Carlsberg V. The complete sequence; comparison with subtilisin $\mathrm{BPN}^{\prime}$; evolutionary relationships. J Biol Chem 243:2184-2191

Stahl ML, Ferrari E (1984) Replacement of the Bacillus subtilis subtilisin structural gene with an in vitro-derived deletion mutation. J Bacteriol 158:411-418

Stanssens P, Opsomer C, McKeown YM; Kramer W, Zabeau M, Fritz HJ (1989) Efficient oligonucleotide-directed construction of mutations in expression vectors by the gapped-duplex DNA method using alternating selectable markers. Nucleic Acids Res $17: 4441-4454$

Towbin H, Staehelin T, Gordon J (1979) Electrophoretic transfer of proteins from polyacrylamide gels to nitrocellulose sheets: procedure and some applications. Proc Natl Acad Sci USA $76: 4350-4354$
Vasantha N, Thompson LD (1986) Secretion of a heterologous protein from Bacillus subtilis with the aid of protease signal sequences. J Bacteriol 165:837-842

Vasantha N, Thompson LD, Rhodes C, Banner C, Nagle J, Filpula $D$ (1984) Genes for alkaline protease and neutral protease from Bacillus amyloliquefaciens contain a large open reading frame between the regions coding for signal sequence and mature protein. J Bacteriol 159:811-819

Wells JA, Ferrari E, Henner DJ, Estell DA, Chen EY (1983) Cloning, sequencing, and secretion of Bacillus amyloliquefaciens subtilisin in Bacillus subtilis. Nucleic Acids Res 11:7911-7925

Wells JA, Powers DB, Bott RR, Katz BA, Ultsch MH, Kossiakoff AA, Power SD, Adams RM, Heyneker HH, Cunningham BC, Miller JV, Graycar TP, Estell DA (1987a) Protein engineering of subtilisin. In: Oxender DL, Fox CF (eds) Protein engineering. Alan R Liss, New York, pp 279-287

Wells JA, Cunningham BC, Graycar TP, Estell DA (1987b) Recruitment of substrate-specificity properties from one enzyme into a related one by protein engineering. Proc Natl Acad Sci USA 84:5167-5171

Wong SL, Doi RH (1986) Determination of the signal peptidase cleavage site in the preprosubtilisin of Bacillus subtilis. J Biol Chem 261 :10176-10181

Communicated by J.W. Lengeler 